\title{
Pengembangan Modul Penyusunan Instrumen Penilaian Pembelajaran Matematika Bagi Guru Berbasis Budaya Jambi
}

\author{
Anisa Ermaida ${ }^{1}$, Kamid $^{2}$, Yantoro $^{3}$ \\ 1, 2, ${ }^{3}$ Program Studi Magister Pendidikan Matematika, Fakultas Pascasrjana, Universitas Jambi \\ Jl. Jambi-Muaro Bulian KM.15 Mandalo Indah Muaro Jambi, Jambi, Indonesia \\ anisa.ermaida@ymail.com
}

\begin{abstract}
Teachers are still making assessment instruments based on the adoption of textbooks that have not touched local culture, especially Jambi culture. This module development research aims to determine the procedures for developing assessment instruments, making modules, developing Jambi culture-based mathematics learning assessment instruments, and module validity. This study uses a development research design with the ADDIE development model. The stages carried out are 1) Analyze, 2) Design, 3) Development, 4) Implement, 5) Evaluation. This research was carried out at SMK N 1 Jambi City, in the odd semester of the 2020/2021 academic year with the research subject being a mathematics teacher. The results of this study were based on the ADDIE development model, namely, at the analysis stage, curriculum analysis, student characteristics analysis, and material analysis were carried out. In the design phase, preparation of the product is carried out, the preparation of the module framework, and the preparation of the assessment instrument. In the development stage, the product was made, then the research instrument used was a closed questionnaire. The implementation stage is the product developed by the material expert team and the design expert team validation, then tested on teachers at SMK N 1 Jambi City. The evaluation stage is through data analysis with validity tests and descriptive statistical data analysis so that the validity is obtained, the data obtained are analyzed qualitatively. The conclusion of this study shows that the module for preparing the assessment instrument for learning mathematics for teachers based on Jambi's culture is valid.
\end{abstract}

Keywords: Module, Mathematic Assessment Instrument, Jambi Culture

\begin{abstract}
Abstrak
Guru masih membuat insrumen penilaian berdasarkan adopsi dari buku matapelajaran yang belum menyentuh budaya lokal khususnya budaya Jambi. Penelitian pengembangan modul ini bertujuan mengetahui prosedur pengembangan instrumen penilaian, pembuatan modul, pengembangan Instrumen penilaian pembelajaran matematika berbasis budaya Jambi, validitas modul. Penelitian ini menggunakan rancangan penelitian pengembangan dengan model pengembangan ADDIE.Tahap yang dilakukan yaitu 1) Analyze, 2) Design, 3) Development, 4) Implement, 5) Evaluation. Penelitian ini dilaksanakan di SMK N 1 Kota Jambi, pada semester ganjil tahun ajaran 2020/2021 dengan subjek penelitian yaitu guru matematika Hasil penelitian ini berdasarkan model pengembangan ADDIE yaitu, pada tahap analisis dilakukan analisis kurikulum, analisis karakteristik peserta didik, analisi smateri. Tahap perancangan dilakukan persiapan pembuatan produk, penyusunan kerangka modul, dan penyusunan instrumen penialain. Tahap pengembangan dilakukan pembuatan produk, kemudian instrumen penelitian yang digunakan adalah angket tertutup. Tahap Implementasi yaitu produk hasil pengembangan di validasi tim ahli materi dan validasi tim ahli desain, kemudian di uji cobakan kepada guru di SMK N 1 Kota Jambi. Tahap evaluasi melalui analisis data dengna uji validitas dan analitis data statistic deskripsif maka diperoleh kevalidan, data yang diperoleh dianalisis secara kualitatif. Kesimpulan penelitian ini menunjujkkan bahwa modul penyusunan instrumen penilaian pembelajaran matematika bagi guru berbasis budaya Jambi sudah valid.
\end{abstract}

Kata kunci: Modul, Instrumen Penilaian Pembelajaran Matematika, Budaya Jambi

Copyright (c) 2021 Anisa Ermaida, Kamid, Yantoro

$\triangle$ Corresponding author: Yantoro

Email Address: yantoro@unja.ac.id (Jl. Jambi-Muaro Bulian KM.15 Mandalo Indah Muaro Jambi, Indonesia)

Received 23 June 2021, Accepted 13 July 2021, Published 06 August 2021

\section{PENDAHULUAN}

Pembelajaran Kurikulum 2013 menekankan penggunaan permasalahannya yang ada di sekitar peserta didik, seperti menggunakan contoh-contoh dari lingkungan tempat tinggal peserta didik. Maka instrumen penilaian pembelajaran matematika sebaiknya menggunakan kebudayaan yang ada ditempat mereka tinggal serta konsep-konsep matematika juga perlu diajarkan dengan mempertimbangkan nilai 
budaya lokal yang berkembang dalam masyarakat di sekitar lingkungan peserta didik. Menurut Daryanto (2013) budaya lokal yang merupakan landasan karakter bangsa, hal ini penting untuk ditanamkan dalam setiap individu, maka nilai budaya sebaiknya diajarkan sejak dini supaya setiap individu mampu memahami, menghargai,memaknai dan menyadari pentingnya nilai budaya dalam beraktifitas. Penanaman nilai budaya bisa dilakukan melalui lingkungan keluarga, sekolah dan masyarakat. Dalam kegiatan pembelajaran di sekolah sebaiknya menggunakan budaya lokal untuk membiasan siswa dengan budaya lokalnya.

Menurut Sardjiyo dan Pannen (2010) menyatakan bahwa pembelajaran berbasis budaya merupakan strategi penciptaan lingkungan belajar dan perancangan pengalaman belajar yang mengintegrasikan budaya sebagai bagian dari proses pembelajaran. Pembelajaran berbasis budaya dilandaskan pada pengakuan terhadap budaya sebagai bagian yang fundamental (mendasar dan penting) bagi guruan sebagai ekspresi dan komunikasi suatu gagasan dan perkembangan pengetahuan. Pembelajaran berbasis budaya, membuat siswa tidak hanya meniru dan menerima informasi yang disampaikan tetapi siswa menciptakan makna, pemahaman, dan mengembangkan pengetahuan yang diperoleh. Proses pembelajaran berbasis budaya tidak hanya mentransfer budaya serta perwujudan budaya tetapi menggunakan budaya untuk menjadikan siswa mampu menciptakan makna, menembus batas imajinasi, dan kreatif dalam mencapai pemahaman yang mendalam tentang mata pelajaran yang dipelajari.

Sementara itu di SMK N 1 Kota Jambi, dalam pembelajaran matematika guru sering menggunakan instrumen penilaian pembelajaran matematika yang ada di buku sering menggunakan instrument penilaian yang hanya menilai pengetahuan matematikanya saja dan tidak memperkenalkan budaya lokal tempat mereka menimba ilmu yakni budaya Jambi. Hal ini nampak pada instrument soal pada kegiatan ujian akhir sekolah semester ganjil tahun pelajaran 2020/2021 untuk mata pelajaran matematika, guru masih membuat insrumen penilaian berdasarkan adopsi dari buku mata pelajaran yang belum menyentuh budaya lokal khususnya budaya Jambi. Maka agar instrumen penilaian pembelajaran matematika yang diberikan guru kepada peserta didik tersusun sistematis, efesien, sesuai dengan budaya lokal yang ada disekitar peserta didik terutama yang berkaitan dengan budaya Jambi maka diperlukan suatu instrumen penilaian pembelajaran matematika pembelajaran yang berkaitan dengan pengalaman peserta didik sehari-hari yang berkaitan dengan budaya Jambi. Maka dalam hal ini akan dikembangkan modul instrumen penilaian pembelajaran matematika bagi guru berbasis budaya Jambi.

Dalam penelitian ini, penelitiakan menggunakan materi geometri dalam pengembangan modul penyusunan instrument.Menurut Kamid et al (2016) materi geometri membutuhkan pendekatan pengajaran yang sesuai agar konsep yang dipelajari bisa dipahami dngan baik oleh peserta didik. Sedangkan menurut Nugraha (2011) Geometri perlu dipelajari karena (1) geometri membantu peserta didik memiliki keyakinan dengan dunianya, (2) geometri dapat mengantarkan pesera didik unuk mengembangkan kemampuan pemecahan masalah, (3) geometri dapat menunjang ilmu pengetahuan lainnya, (4) geometri digunakan banyak orang dalam kehidupan sehari-hari (5) geometri penuh dengan teka-teki menyenangkan. Maka dalam pengembangan modul ini akan digunakan materi geometri. 
Berdasarkan uraian diatas, maka perlu adanya inovasi dalam Instrumen penilaian pembelajaran matematika matematika, maka peneliti termotivasi untuk melakukan penelitian denganjudul Pengembangan Modul penyusunan instrumen penilaian pembelajaran matematika bagi guru berbasis budaya Jambi.Dengan tujuan untuk mengetahuiproses pengembangan modul penyusunan instrumen penilaian pembelajaran matematika bagi guru berbasis budaya Jambi.

\section{METODE}

Jenis penelitian ini yaitu penelitian pengembangan, metode yang digunakan adalah metode penelitian dan pengembangan. Penelitian ini dilaksanakandi SMK Negeri 1 Kota Jambi, pada semester ganjil tahun pelajaran 2020/2021. Prosedur pelaksanaan penelitian pengembangan Modul ini menggunakan model ADDIE yang terdiri dari tahap yang dilakukanyaitu 1) Analyze (analisis), 2) Design (Perancangan), 3) Development (Pengembangan), 4) Implement (Pelaksanaan), 5) Evaluation (Evaluasi). ADDIE adalah konsep pengembangan produk yang memiliki tujuan untuk membangun pembelajaran berbasis kinerja (Branch, 2009). Kerangka ADDIE merupakan kerangka yang paling populer dalam mendesain dan mengembangkan produk baik untuk tipe aliran berpikir analitis maupun ilmiah.Hal ini dikarenakan kerangka ADDIE memiliki kerangka kerja yang runut dan sistematis dalam mengorganisasikan rangkaian kegiatan dalam penelitian pengembangan (Sugiyono, 2010).

Jenis data dalam penelitian ini adalah data kualitatif, yang didapat dari angket validasi ahli materi, ahli desain pembelajaran, ahli desain produk dan praktisi yang dilakukan oleh guru matematika. Istrumen yang digukakan dalam penelitian ini adalah angket tertutup yang diberikan kepada validator ahli dan praktisi.

Kreteria yang ingin dicapai pada instrumen validasi materi untuk produk yaitu kelayakan isi, kebahasaan dan sajian. Sedangkan kreteria pada instrumen validasi desain yaitu layout dan tata letak, desain cover, penggunaan font dan mutu gambar. Sedangkang kreteria pada angket uji coba lapangan yaitu, tampilan cover, materi modul, topik permasalahan, gambar dalam modul, bahasa yang digunakan, latihan soal yang ada, urutan materi, materi dalam modul dan dapat diunakan sebagai sumber belajar.

\section{HASIL DAN DISKUSI}

\section{Prosedur Pengmbangan Modul}

Modul panduan pembuatan instrumen penilaian pembelajaran matematika berbasis budaya Jambi terdiri dari tiga bab. Modul yang dikembangkan menggunakan model pengembangan ADDIE yang terdiri dari tahap Analize, Design, Development, Implement dan Evaluation.

Analize

Tahap analisis ini dilakukan analisis kurikulum, analisis karakteristik peserta didik, analisis materi. Berdasarkan informasi yang diperoleh peneliti, bahwa guru masih menggunakan soal dengan jenis soal pilihan ganda dan esai tetapi tidak ada mengaitkan kedalam budaya Jambi. Dengan itu, maka penilaian yang dilakukan oleh guru hanya bersifat objektif dan sesuai dengan LKS ataupun buku cetak saja yang tidak 
dapat menggambarkan kemampuan siswa dengan jelas bahkan tidak ada permasalahan nyata dari budaya daerah dari siswa tersebut yakni budaya Jambi yang dapat membuat siswa lebih berkarakter, sebagaimana siswa berkemampuan kognitif tinggi hanya diukur oleh keberuntungan saja bukan dari kemampuan kognitif siswa maupun tidak adanya daya pikat dan pehaman siswa terhadap budaya daerahnya yakni daerah Jambi, sedangkan untuk siswa yang cerdas secara kognitif bisa saja berkemampuan rendah jika menggunakan tes pilihan ganda, selain itu guru juga tidak dapat melihat dimana kelemahan siswa dalam memahami sebuah materi pembelajaran yang diajarkan, sehingga guru kesulitan untuk menganalisis dimana ketidakmampuan siswa dalam memahami materi tersebut.

Hal ini sejalan dengan apa yang dikatakan Lantas (2004) dalam sistem penilaiannya masih didominasi oleh satu metode penilaian yaitu tes kertas dan pensil (pencil and paper test) yang hanya mengukur ingatan siswa terhadap informasi-informasi faktual dan prosedurproseduralgoritmasajateskertasdanpensildapatberupapilihanbenar-salah, mengisi kotak kosong, pilihan berganda dan tes dengan jawaban singkat. Zainul dan Nasution (2001) Menggunakan istilah penilaian tradisional untuk tes kertas dan pensil yang lebih khusus lagi adalah tes baku yang menggunakan perangkat tes objektif. Dominasi tes ini terlihat dari soal-soal Ujian Nasional (UN) dan Seleksi Nasional Masuk Perguruan Tinggi Negeri (SNMPTN). Penggunaan tes objektif dalam soal- soal tersebut mendorong para guru memberikan latihan-latihan pada siswa untuk menjawab soal-soal bentuk ini. Bahkan para siswa diajarkan bagaimana "trik" untuk menyelesaikan soal-soal yang demikian.

Selain itu, untuk soal uraian guru banyak mengatakan kesulitan dalam membuat instrumen, sehingga guru merujuk hanya kepada LKPD yang telah disediakan sekolah maupun penerbit-penerbit buku yang telah ada, selain itu ada beberapa guru yang masih menggunakan buku-buku lama yang sudah tidak relevan dengan permasalahan saat ini, disini terdapat kesenjangan antara materi yang disampaikan dengan instrumen tes yang digunakan sebagaimana pembelajaran disekolah seharusnya bisa menjadi bekal siswa dalam memecahkan setiap masalah pada kehidupan sehari-hari sehingga pembelajaran disekolah lebih bermakna dan berguna untuk diri siswa sendiri maupun dilingkungannya. Menurut hasil penelitian Idris dan Nor (2010) yang menyampaikan bahwa proses pembelajaran dengan memanfaatkan Information, Communication, Technology (ICT) terutama pemanfaatan komputer maka akan meningkatkan kemampuan berpikir kreatif matematis siswa. Penelitian Hapizoh (2019) yang menyatakan bahwa pembelajaran terintegrasi STEM mampu meningkatkan kemampuan berpikir kreatif matematis siswa.

Selain itu terdapat juga dalam mendesain sebuah soal pemecahan masalah guru merasa kesulitan untuk membuat Instrumen penilaian pembelajaran matematika yang dapat menilai kemampuan kognitif siswa, karena dalam pembelajaran matematika terdapat banyak model pemecahan masalah yang diketahui, sehingga jenis pemecahan masalah satu dengan yang lain tidak mungkin sistem penilaiannya sama sehingga dalam pemecahan masalah dapat menilai secara detail yang dikerjakan siswa sesuai dengan kemampuan siswa.

\section{Design}

Tahap perancangan dilakukan persiapan pembuatan produk, Menurut Branch (2009) pada tahap ini 
semua hal yang dibutuhkan akan dibuat sesuai dengan yang ada pada tahap analisis. Semua mulai direalisasikan untuk menghasilkan sebuah produk yang dapat membantu guru dalam mendesain Instrumen Penilaian Pembelajaran Matematika berbasis budaya Jambi.

\section{Merancang Kerangka Modul}

Penyusunan modul diawali dengan mencari berbagai referensi yang dibutuhkan. Penempatan langkah-langkah ini dapat dilihat dalam kerangka modul Instrumen Penilaian Pembelajaran MatematikaBerbasis budaya Jambi pada tabel berikut:

Tabel 1. Kerangka Modul Instrumen Penilaian Pembelajaran Matematika Berbasis Budaya Jambi

\begin{tabular}{|c|c|}
\hline Kerangka & Isi Kerangka Pendahuluan \\
\hline A. Judul & Gambaran umum isi dari modul \\
\hline B. Daftar isi & Menyajikan topik-topik yang akan di bahas \\
\hline C. Peta Informasi & $\begin{array}{l}\text { Menjelaskan tentang bagaimana pengguna mempelajari materi yang } \\
\text { ada dalam modul tersebut }\end{array}$ \\
\hline $\begin{array}{ll}\text { D. Dasar } & \text { tujuan } \\
\text { kompetensi } & \end{array}$ & $\begin{array}{l}\text { Menjelaskan tentang kompetensi, tujuan pembelajaran } \\
\text { pengalaman belajar yang harus dikuasai pengguna modul }\end{array}$ \\
\hline $\begin{array}{l}\text { E. Pendahuluan/tinjauan } \\
\text { umum materi }\end{array}$ & $\begin{array}{l}\text { (1) memberikan gambaran umum mengenai isi materi Modul, } \\
\text { (2) meyakinkan pengguna bahwa materi yang akan dipelajari dapat } \\
\text { bermanfaat bagi mereka } \\
\text { (3) meluruskan harapan pengguna mengenai materi yanag akan } \\
\text { dipelajari, } \\
\text { (4) mengaitkan materi yang telah dipelajari dengan materi yang akan } \\
\text { dipelajari, } \\
\text { (5) memberikan petunjuk bagaimana mempelajari materi yang } \\
\text { disajikan. }\end{array}$ \\
\hline $\begin{array}{llr}\text { F. } & \text { Hubungan } & \text { dengan } \\
& \text { materi } & \text { atau } \\
& \text { pembelajaran } & \text { yang } \\
& \text { lain } & \\
\end{array}$ & Menjelaskan bagaimana cara mengakses materi \\
\hline G. Uraian Materi & $\begin{array}{l}\text { Menjelaskan secara terperinci tentang materi pembelajaran yang } \\
\text { disampaikan dalam Modul }\end{array}$ \\
\hline H. Penugasan & $\begin{array}{l}\text { Berisilatihan-latihan soal yang dikembangkan dari kompetensi yang } \\
\text { diharapkan. }\end{array}$ \\
\hline I. Rangkuman & Menelaahhal-hal pokok dalam Modul yang telah dibahas. \\
\hline J. Glossary & Berisikandefinisi-definisikonsep yang dibahasdalamModul \\
\hline K. Tesakhir & $\begin{array}{l}\text { Latihanyang } \\
\text { penggunakerjakansetelahmempelajarisuatubagiandalamModul }\end{array}$ \\
\hline L. Indeks & $\begin{array}{l}\text { Memuatistilah- } \\
\text { istilahpentingdalamModulsertahalamandimanaistilahtersbutditemukan }\end{array}$ \\
\hline
\end{tabular}

\section{Penulisan Draf Modul}

Komponen yang terdapat dalam draf modul penyusunan Instrumen Penilaian Pembelajaran Matematikaberbasis budaya Jambi ini meliputi daftar isi, petunjuk penggunaan, dasar tujuan kompetensi, materi, penugasan, rangkuman, glosary, tes akhir, dan indeks. 
Pengembangan Modul Penyusunan Instrumen Penilaian Pembelajaran Matematika Bagi Guru Berbasis Budaya Jambi, Anisa Ermaida, Kamid, Yantoro
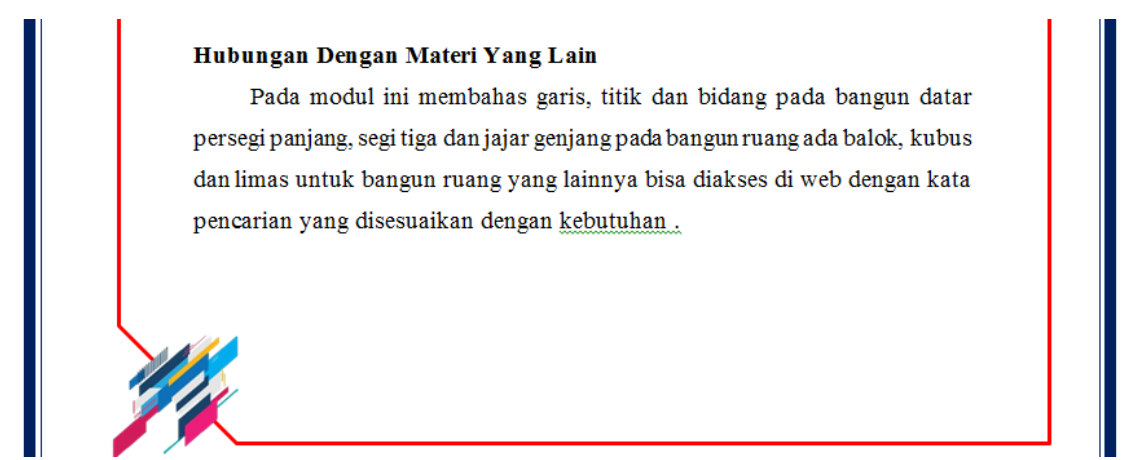

Gambar 1. Draf Hubungan dengan Materi atau Pembelajaran yang lain
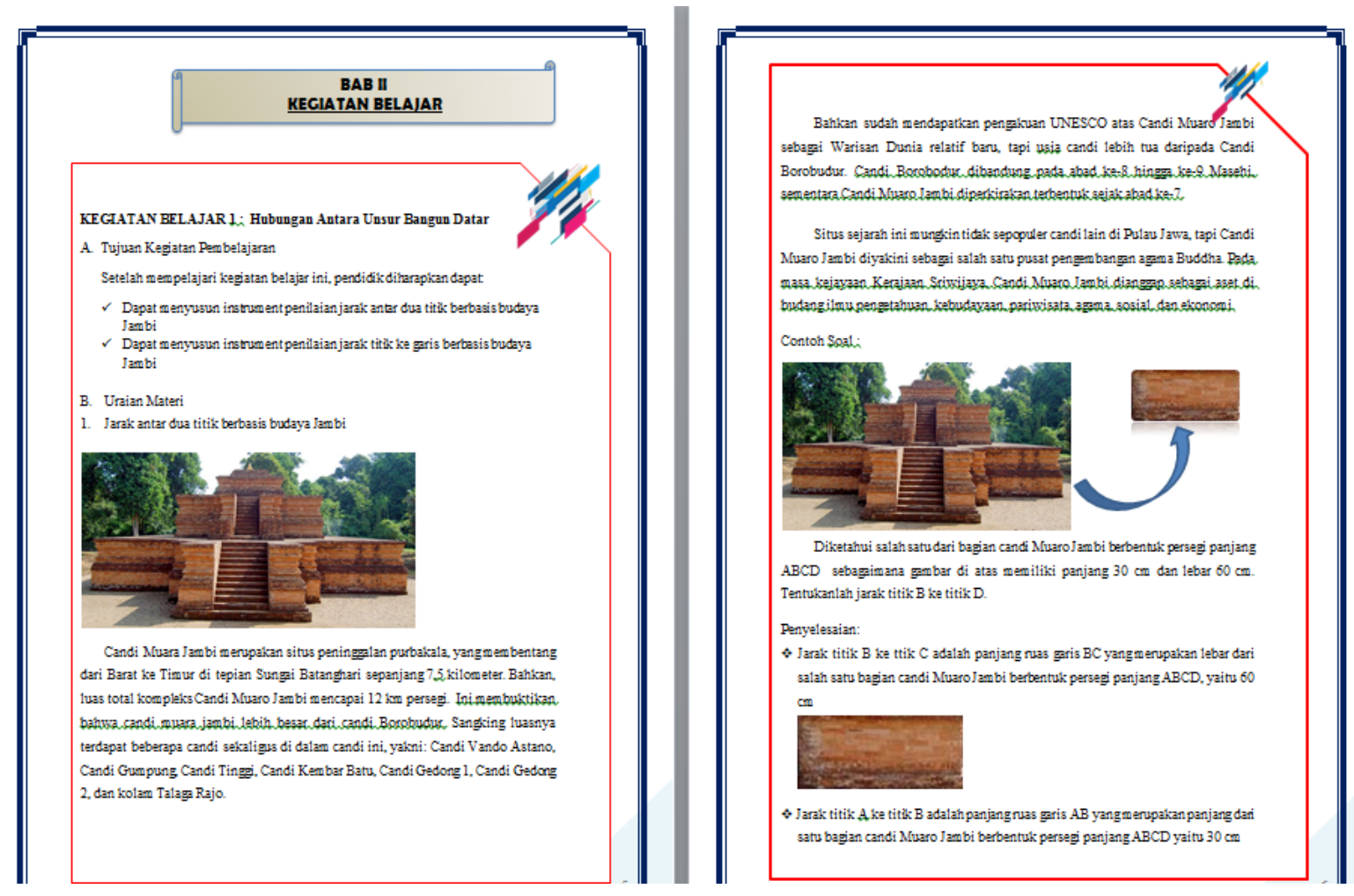

Gambar 2. Draf Uraian Materi

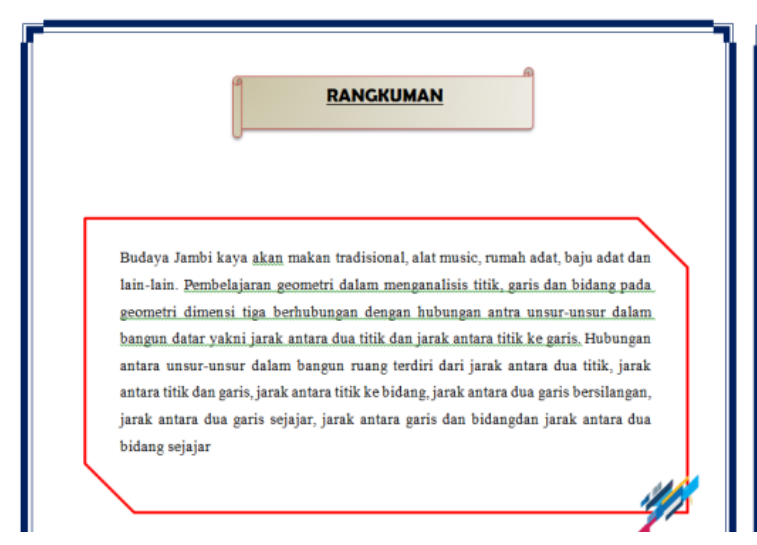

Gambar 3. Draf Penugasan

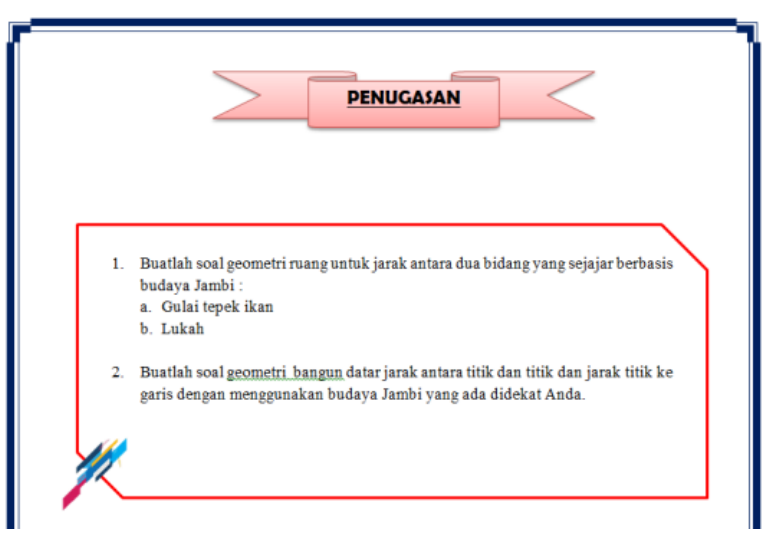

Gambar 4. Draf Rangkuman 


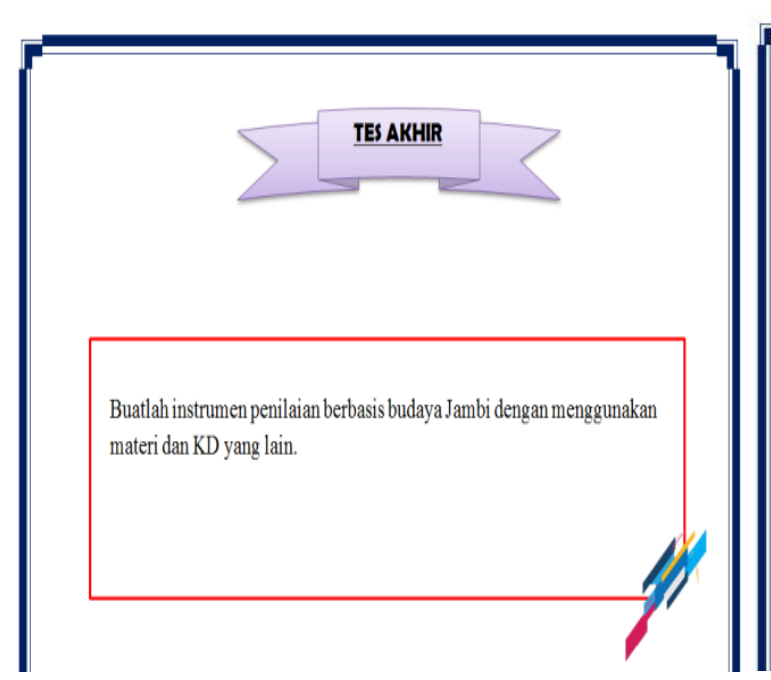

Gambar 5. Draf Glosary

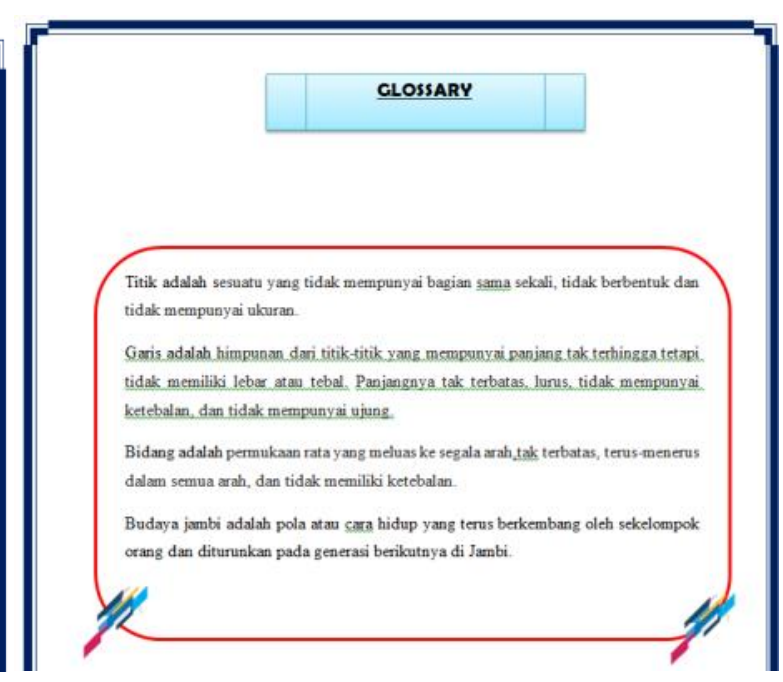

Gambar 6. Draf tes akhir

\section{Development}

Tahap pengembangan adalah proses mewujudkan blue - print, atau desain menjadi kenyataan. Produk yang dihasilkan yaitu modul penyusunan Instrumen Penilaian Pembelajaran Matematikaberbasis budaya Jambi pada materi geometri, tahapan pembuatan modul ini melalui beberapa tahapan, yaitu: 1) membuat media yang telah dirancang, 2) setelah media selesai dirancang kemudian di cetak sehingga modul dapat digunakan secara langsung, 3) selanjutnya modul tersebut di validasi, uji validasi dilakukan untuk mengetahui tingkat keaslian modul yang telah dirancang. Proses validasi dilakukan oleh para ahli yang kompeten di bidangnya. Berdasarkan hasil validasi, modul dapat diketahui apakah valid atau tidak, atau layak untuk diujicoba kepada pengguna atau tidak.

Setelah dilakukan perbaikan, dan modul dinyatakan valid, kegiatan berikutnya adalah melakukan uji kepraktisan. Dengan kata lain, modul yang telah valid diujicobakan kepada guru. Uji coba dilaksanakan di sekolah yang telah ditentukan sebelumnya. Uji coba dilakukan untuk mengetahui kepraktisan dan efektivitas modul penyusunan Instrumen Penilaian Pembelajaran Matematikaberbasis budaya Jambi.l kepraktisan diperoleh dari hasil pengisian angket kepraktisan oleh guru. Untuk lebih jelas, kegiatan yang dilakukan pada tahap pengembangan dapat dipaparkan sebagai berikut:

\section{Validasi Modul}

Berikut hasil validasi modul dari validasi ahli media dan validasi ahli materi.

\section{Validasi ahli media}

Modul yang telah dibuat, kemudian divalidasi oleh ahli media. Validasi ahli media dilakukan oleh Dr. Nizlel Huda, M.Kes. merupakan dosen program studi magister pendidikan matematika Universitas Jambi yang merupakan seorang yang ahli dan berpengalamandibidangdesaininstrumen. Setelah ahli media melihat dan menyimak isi modul, saran perbaikan yang dianjurkan oleh ahli media adalah:

1. Pada cover cantumkan gambar yang berhubungan dengan materi modul.

2. Buat dua jenis cover yaitu cover depan dan cover kedua untuk penulisan identitas pengguna. 
Pengembangan Modul Penyusunan Instrumen Penilaian Pembelajaran Matematika Bagi Guru Berbasis Budaya Jambi, Anisa Ermaida, Kamid, Yantoro

3. Kualitas gambar harus diperbaiki dan sesuaikan dengan lingkungan tempat penelitian

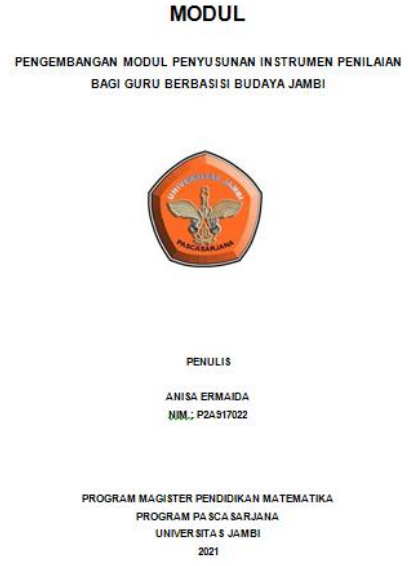

Gambar 7. Cover Sebelum di Revisi

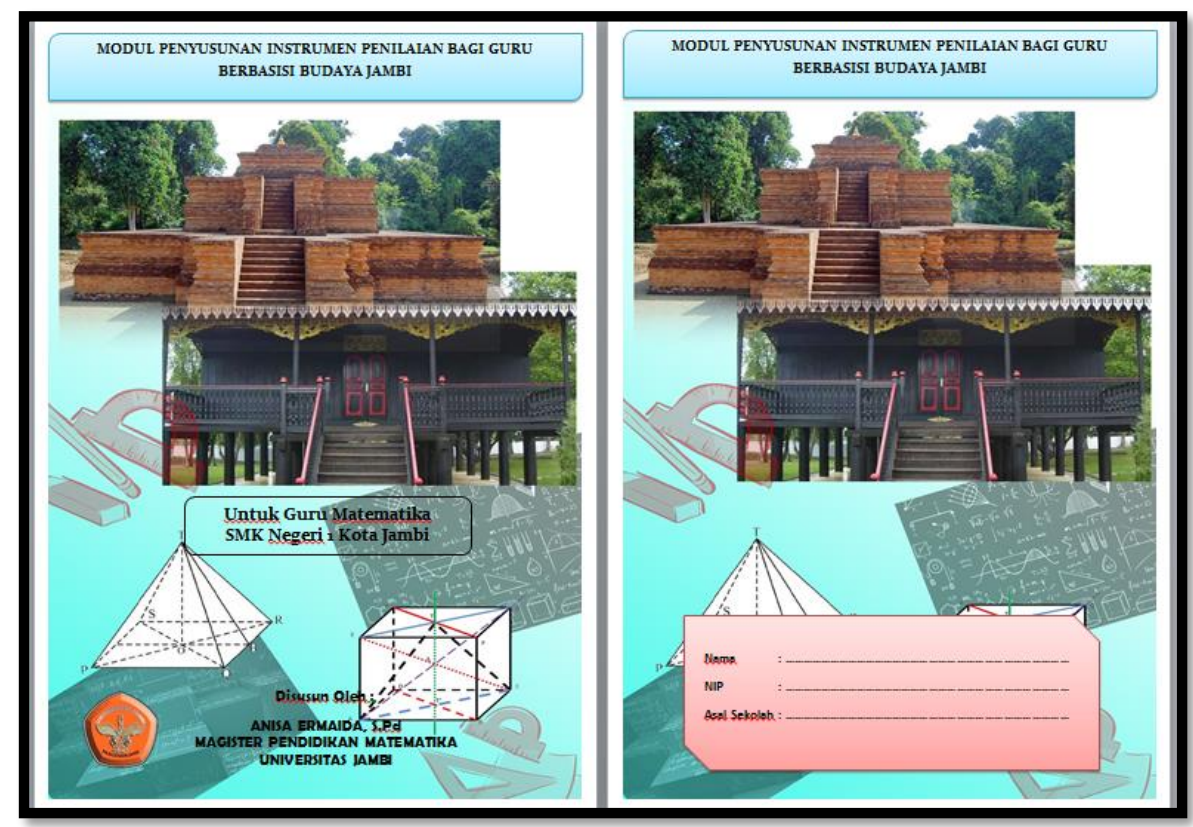

Gambar 8. Cover Sesudah di Revisi

\section{Validasi Ahli Materi}

Validasi kedua adalah validasi materi yang dilakuan oleh Dr. Drs. Syaiful, M.Pd. merupakan dosen program studi magister pendidikan matematika Universitas Jambi yang merupakan ahli materi. Berdasarkan validasi dari ahli materi, terdapat beberapa hal yang dapat dideskripsikan yaitu (1) kelayakan isi, (2) kelayakan kebahasaan dan, (3) kelayakan sajian. Untuk lebih jelas dipaparkan sebagai berikut:

1. Kelayakan Isi

a. Materi yang ada di dalam modul sesuai denga kebutuhan pengguna.

b. Materi yang ada di dalam modul memberikan manfaat dan dapat menambah wawasan bagi pengguna 
modul.

c. Instrumen Penilaian Pembelajaran Matematika sudah sesuai dengan unsur budaya Jambi.

d. Latihan yang ada di dalam modul sudah sesuai dengan materi yang ada di dalam modul.

e. Latihan yang diberikan penyusun dapat dipahami oleh pengguna.

f. Latihan dapat mengungkapkan kemampuan pendidik dalam menyusun Instrumen Penilaian Pembelajaran MatematikaBerbasis Budaya Jambi.

2. Kelayakan Kebahasaan

a. Bahasa yang digunakan dalam modul mudah dipahami.

b. Tidak menggunakan kata atau kalimat yang dapat menimbulkan penafsiran yang berbeda.

c. Penggunaan bahasa dalam modul sudah sesuai dengan EYD.

3. Kelayakan Sajian

a. Langkah-langkah kerja yang disajikan di dalam modul sudah jelas.

b. Materi modul yang disajikan sesuai dengan budaya Jambi.

c. Kriteria penilaian terhadap Instrumen Penilaian Pembelajaran MatematikaBerbasis budaya Jambi sudah sesuai.

Berdasarkan hasil validasi yang dilakukan oleh validator ahli materi dan validator ahli media, dapat diperoleh kesimpulan bahwa modul penyusunan Instrumen Penilaian Pembelajaran MatematikaBerbasis budaya Jambi sudah sesuai, sehingga layak untuk diujicobakan.

\section{Implementasi}

Pada tahap ini modul dilakukan uji coba kepada pengguna (guru), yang disebut sebagai pengguna (guru) adalah seseorang yang berpengalaman dalam membelajarkan matematika dan sebagai salah satu guru yang aktif melakukan pembelajaran di SMK N 1 kota Jambi. Pada tahap ini terdapat lima praktisi untuk menilai modul yang telah valid oleh ahli materi dan desain instrumen, ini bertujuan agar modul menjadi lebih baik lagi dengan mengharapkan masukan dari para praktisi pada bidang pembelajaran matematika disekolah, berikut flowchart pada tahap uji coba praktisi serta instrumen penilaian pembelajaran matematika praktisi yang terletak padalampiran.

\section{Data Hasil Uji Coba Praktisi}

Pada tahap ini, ahli prktisi yakni pengguna diberikan modul yang telah di validasi oleh ahli desain instrumen dan ahli materi dimana pada tahap ini dilakukan untuk medapatkan data tanggapan dari ahli praktisi yakni pengguna yang sudah berpengalaman dalam dunia pendidikan dan pembelajaran disekolah agar modul yang dikembangkan dapat menambah wawasan dan keterampilan pengguna dalam membuat instrumen penialaian.

Pada tahap uji coba praktisi terdapat banyak masukan yang membangun dalam meperbaiki modul yang dikembangkan, dengan adanya masukan seperti inimaka akan sangat berguna dan sangat dibutuhkan untuk perbaikan modul kedepannya, ada beberapa yang menjadi pokok perhatian setiap guru pada modul ini, guru menganggap cover yang digunakan kurang menarik, dan diperbaiki oleh peneliti modul yang dikembangkan menjadi lebih menarik dan semua guru merekomendasikan untuk digunakan dalam 
Instrumen Penilaian Pembelajaran Matematikaketika melaksanakan KBM dengan judul materi yang berbeda tetapi tetap dengan Instrumen penilaian pembelajaran matematika berbasis budaya Jambi.

Setelah melalui proses penelitian yang tahapannya meliputi:pertama,manganalisis kebutuhan, meninjau literatur, mendesain modul panduan dalam mandesain Instrumen Penilaian Pembelajaran MatematikaBerbasis budaya Jambi, mengembangkan modul pengembanan dalam mendesain Instrumen Penilaian Pembelajaran Matematikabagi guru matematika Berbasis budaya Jambi, kedua memvalidasi kepada seorang ahli materi dan seorang ahlidesain instrumen, kemudian setelah di nyatakan layak sesuai dengan saran yang di berikan, sejalan dengan pendapat Sugiyono (2010) bahwa validasi produk dapat dilakukan dengan cara menghadirkan beberapa pakar atau tenaga ahli yang sudah berpengalaman untuk menilai produk baru yang dirancang tersebut sehingga dapat diketahui kelemahan dan kekurangannya.

Setelah selesai mendesain modul ini, kemudian modul pengembangan Instrumen Penilaian Pembelajaran Matematikabagi guru Berbasis budaya Jambiini divalidasi dengan tenaga ahli materi dan ahli desain instrumen. Hasil penilaian terhadap validasi materi diterangkan oleh ahli semua mendapat hasil yang baik, dan sesuai dengan instrumen yang telah diajukan oleh penulis. Jadi, dapat diambil kesimpulan bahwa materi dalam modul pengembangan isntrumen penilaian bagi guru berbassi budaya Jambi ini sudah dibuat dengan baik dan benar sesuai dengan kompetensi yang akan dicapai.

Untuk ahli desain instrumen, hasil penilaian terhadap validasi desain instrumen diterangkan oleh ahli semua mendapat hasil yang baik, dan sesuai dengan instrumen yang telah diajukan oleh penulis. Jadi, dapat diambil kesimpulan bahwa desain instrumen dalam modul pengembangan Instrumen Penilaian Pembelajaran Matematika bagi guru Berbasis budaya Jambi sudah dibuat dengan baik dan benar sesuai dengan kompetensi yang akan dicapai, sesuai dengan teori-teori multimedia oleh Mayer (2002) yang digunakan sebagai acuan.

Setelah itu peneliti merevisi desain instrumen yang terdapat pada modul sesuai dengan saran dan komentar yang diberikan oleh validator ahli setelah itu divalidasi kembali oleh ahli materi dan ahli mengatakan modul layak untuk di uji cobakan dilapangan tanpa revisi.Hal ini sesuai dengan pendapat Nieveen (1999) bahwa indikator untuk mengetahui kevalidan suatu media yaitu dengan melakukan validasi oleh para ahli. Validasi yang dilakukan pada penelitian ini merupakan proses penilaian tentang rancangan produk yang dilakukan dengan memberi komentar berdasarkan pemikiran rasional dan tanpa uji coba di lapangan. Berdasarkan keterangan diatas, maka modul ini adalah valid. Valid tergambar dari hasil komentarvalidator, dimana semua validator menyatakan bahwa modul memenuhi validitas materi, dan validitas desain instrumen layak digunakan tanparevisi. Berdasarkan dari uraian diatas hasil validasi tersebut, sesuai dengan teknik analisis data menurut Rusdi (2018) maka dapat disimpulkan bahwa produk modul yang dikembangkan telah valid dan dapat digunakan atau diimplementasikan pada ke tahapan pengujian selanjutnya.

Setelah modul dihasilkan melalui validasi, maka langkah selanjutnya modul tersebut dinilai oleh pengguna yang telah berpengalaman mengajar di SMK N 1 Kota Jambi.Agar modul dapat digunakan menurut pandangan penggunayang berada di sekolah makapenelititerjun langsung pada lapangan. Terdapat 
5 orang pengguna di SMK N 1 Kota Jambi yaitu: Ibu Deswita, S.Pd, Ibu Lestariyani, S.Pd, Ibu Maryam, S.Pd, Ibu AR. Nefrida, S.Pd, M.Pd dan, IbuNeniMarsolina, S.Pd, M.Pd

Berdasarkan penilaian pada uji coba pengguna ini dengan 5 orang guru matematika di SMK N 1 Kota Jambi, diperoleh banyak komentar dan saran yang telah dijabarkan diatas, dimana modul ini "layak untuk digunkan dengan tanpa revisi."Sehingga modul pengembangan instrumen penilaian pembelajaran matematika bagi guru berbasis budaya Jambi ini dapat dikatakan sudah sesuai dengan pesan yang disampaikan, keterkaitan satu dengan yang lain, dan prosedur dalam membuat sebuah instrumen mudah digunakan. Sesuai dengan pendapat Subakti et.al (2021) menyatakan bahwa E-LKPD yang dikembangkan secara bersama menunjukkan respon yang sangat positif serta menyepakati bahwa produk tersebut praktis dan layak untuk digunakan. Penelitian Vezzali et al. (2016) yang menyatakan bahwa ketika siswa melakukan kegiatan pembelajaran yang di dalamnya terlibat dengan budaya maka akan berdampak kepada peningkatan kemampuan berpikir kreatif siswa. Serta penelitian Supriadi (2017) menyampaikan bahwa melalui kegiatan dan model pembelajaran berbasis etnomatematika dapat meningkatkan kemampuan berpikir kreatif matematis peserta didik.

Adapun Instrumen penilaian pembelajaran matematika berbasis budaya Jambi yang telah disusun oleh pengguna adalah sebagai berikut:

\begin{tabular}{|l|l|}
\hline Materi 1 & Permutasi \\
\hline KD & $\begin{array}{l}\text { 3.25. Menganalisis kaidah pencacahan permutasi dan kombinasi } \\
\text { pada masalah kontekstual }\end{array}$ \\
\hline Indikator Soal & Menentukan nilai permutasi \\
\hline Level Kognitif & 2 \\
\hline
\end{tabular}

\section{Soal 1 :}

Perhatikan jenis makanan tradisional khas Jambi di bawah ini!

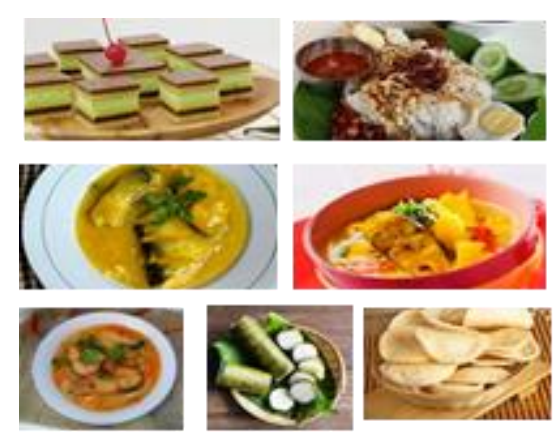

Gambar di atas merupakan makanan khas Jambi yang sering kita temui di sekitar kita. Ada putri kandis, nasi gemuk, gulai patin, tempoyak, tepek ikan, lemang dan kerupuk ikan. Jika ke tujuh jenis makanan ini berada di satu meja makan, berapa banyak tampilan yang bisa disajikan jika:

1. Semua jenis makanan di atas tidak memiliki peraturan posisi letak.

2. Lepek ikan, lemang, dan tempoyak harus berdampingan.

3. Lepek ikan, lemang, dan tempoyak keduanya tidak boleh disajikan berdampingan. 
Pengembangan Modul Penyusunan Instrumen Penilaian Pembelajaran Matematika Bagi Guru Berbasis Budaya Jambi, Anisa

\section{Penyelesaian 1:}

1. Banyak unsur, $\mathrm{n}=6$

${ }_{6} \mathrm{P}$ estis $=(7-1) !=6 !=720$ susunan

2. Jika lepek ikan, lemang dan tempoyak harus berada pada posisi berdampingan, maka jumlah unsur dalam siklus menjadi 5 unsur. Sehingga banyak susunan letak $(5-1) !=4 !=24$. Dan lepek ikan lemang dan tempoyak dapat bertukar tempat sebanyak 3 kali $(3 !)=6$. Maka banyak susunan tata letak adalah $24 \times 6=144$ susunan.

3. Posisi lemang, nasi uduk, tepek ikan, tidak boleh berdampingan, jadi banyak susunan $720-144=$ 576 susunan.

\begin{tabular}{|l|l|}
\hline Materi 2 & Rotasi \\
\hline KD & $\begin{array}{l}\text { Menentukan Masalah Konstekstual Berkaitan Dengan Trasfomal } \\
\text { Geometri }\end{array}$ \\
\hline Indikator Soal & Menentukan nilai permutasi \\
\hline Level Kognitif & 3 \\
\hline
\end{tabular}

\section{Soal 2:}

Perhatikan gambar di bawah ini!

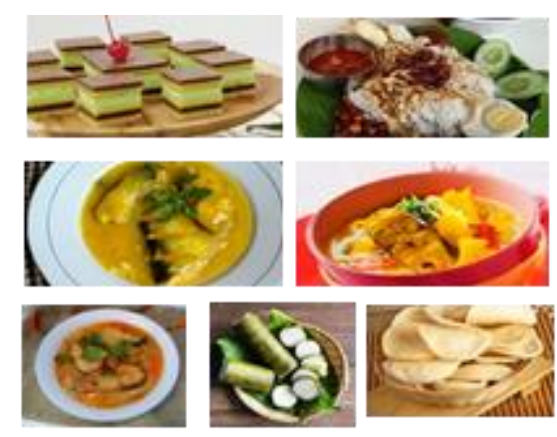

Lemang merupakan makanan khas daerah Jambi yang sering kita temui di sekitar kita. Diketahui sebuah lemang dimana ketika dilihat dari depan berbentuk persegi panjang ABCD, karena bagian lemang ABCD sudah masak maka lemang akan dirotasikan $90^{\circ}$ berlawanan arah jarum jam. Jika $\mathrm{A}(0,0), \mathrm{B}(2,0), \mathrm{C}(2,5)$ dan $\mathrm{D}(0,5)$ dan lemang $\mathrm{ABCD}$ dirotasikan terhadap pusat $\mathrm{P}(1,-6)$. Maka tentukanlah bayangan lemang ABCD.

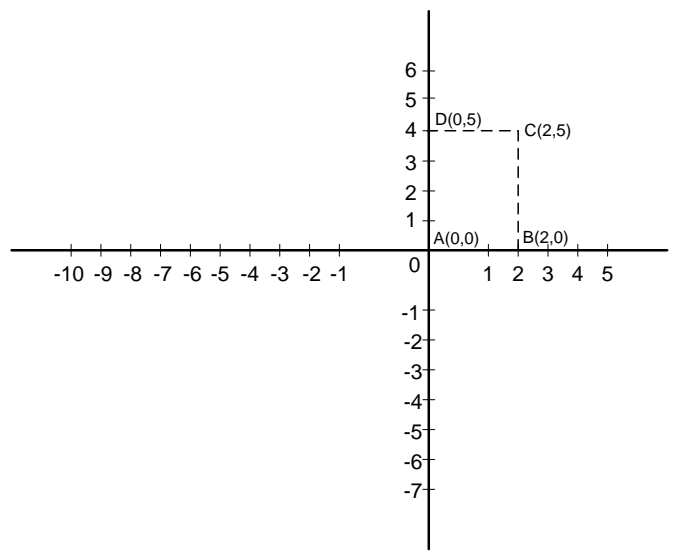

Gambar koordinat titik A, B, C dan D 


\section{Penyelesaian 2:}

Titik A
A $(0,0)=x=0 \quad y=0$
$\mathrm{B}=\mathrm{x}=2 \mathrm{y}=0$
$D=x=0 \quad y=5$
$P(1,-6)=a=1, b=-6$
$\mathrm{C}=\mathrm{x}=2 \mathrm{y}=\mathrm{z} 5$

Titik A

$$
\begin{aligned}
& x^{\prime}-a=(x-a) \cos ^{0}-(y-b) \sin ^{0} \\
& \left.x^{\prime}-1=(0-1) \cos 90^{\circ}-(0-(-6)) \cos 90^{0}\right) \\
& x^{\prime}-1=0-6 \\
& x^{\prime}=-6 \\
& y^{\prime}-b \quad=(x-a) \sin ^{0}+(y-b) \cos ^{0} \\
& y^{\prime}-(-6)=(0-1) \sin 90^{0}+\left(0-(-6) \cos 90^{\circ}\right) \\
& y^{\prime}+6 \quad=-1+0 \\
& y \quad=-7
\end{aligned}
$$

$A^{\prime}=(-6,-7)$

\section{Titik B}

$$
\begin{aligned}
& x^{\prime}-1=(2-1) \cos 90^{\circ}-(0-(-6)) \cos 90^{0} \\
& x^{\prime}-1=0-6 \\
& x^{\prime}=-5 \\
& y^{\prime}-(-6)=(2-1) \sin 90^{0}+\left(0-(-6) \cos 90^{0}\right. \\
& y^{\prime}+6=1+0 \\
& y^{\prime}=-5 \\
& B^{\prime}=(-5,-5) \\
& C^{\prime}= \\
& x^{\prime}-1=(2-1) \cos 90^{\circ}-(5-(-6)) \sin 90^{\circ} \\
& x^{\prime}-1=1-11 \\
& x^{\prime}=-10 \\
& y^{\prime}-(-6)=(2-1) \sin 90^{\circ}+\left(5-(-6) \cos 90^{0}\right. \\
& y^{\prime}-(-6)=1-0 \\
& y^{\prime} \quad=-5
\end{aligned}
$$




$$
\begin{aligned}
& C^{\prime}=(-10,-5) \\
& D^{\prime}= \\
& x^{\prime}-1=(0-1) \cos 90^{0}-(5-(-6)) \sin 90^{0} \\
& x^{\prime}-1=0-11 \\
& x^{\prime}=-10 \\
& y^{\prime}-(-6)=(0-1) \sin 90^{0}+\left(5-(-6) \cos 90^{0}\right) \\
& y^{\prime}+6 \quad=-1+0 \\
& y^{\prime} \quad=-7 \\
& \text { D'= (-10,-7) } \\
& \text { Maka koordinat bayangannya adalah A'(-5,-7), B'(-5,-5), C'(-10,-5), D'(-10,-7) }
\end{aligned}
$$

\section{KESIMPULAN}

Berdasarkan hasil penelitian pengembangan yang telah dilaksanakan, dapat disimpulkan bahwa proses tahapan yang dilakukan dalam mengembangkan modul pengembangan instrumen penilaian pembelajaran matematikabagi guru berbasis budaya Jambi adalah sebagai berikut:

1. Analisisis Masalah Dan Kebutuhan

Pada tahap ini peneliti membaca dari beberapa literatur yakni jurnal dan melihat dari fenomena yang ada yaitu masih digunakannya tes pilihan ganda pada penilaian pembelajaran di sekolah dan menggunakan keterkaitan soal dengan bukannya budaya Jambi.

2. Desain Produk

Dalam proses mendesain modul, peneliti berkonsultasi oleh dosen pembimbing dalam pembuatannya, dan merujuk pada sumber para ahlimaupun sumber yang di kutip oleh peneliti, sehingga diperoleh modul dengan 3 bab bagian penting yaitu, pendahuluan, konsep dan prosedur dan contoh yang memaparkan cara dalam mengembangan Instrumen Penilaian Pembelajaran Matematika Berbasis budaya Jambi.

3. Validitas

Dalam proses validasi, peneliti menggunakan 2 validasi yaitu validasi desain instrumen dan validasi materi. Pada validasi produk ini, peneliti melibatkan 2 orang dosen magister pendidikan matematika, yaitu Dr. Nizlel Huda, M.Si., dan Dr. Syaiful, M.Pd.

4. Uji Coba Praktisi

Pada proses uji coba praktisi, responden untuk menilai produk yang telah didesain dan di validasi ahli ini sebanyak 5 orang guru di SMK N 1 Kota Jambi, dimana mereka sudah berpengalaman dalam mengajar di SMK N 1 Kota Jambi. Pada masing-masing responden diberi sebuah Instrumen penilaian pembelajaran matematika produk untuk menilai produk yang dikembangkan berbentuk angket terbuka 
untuk memberi masukan kepada peneliti agar produk yang dikembangkan menjadi maksimal dalam segi kualitas.

\section{REFERENSI}

Branch, R. M. (2009). Instructional design: The ADDIE approach (Vol. 722). Springer Science \& Business Media.

Daryanto. (2013). Menyusun modul bahan ajar untuk persiapan guru dalam mengajar. Yogyakarta: Gava Media.

Hapizoh. (2019). Penerapan Discovery Learning Terintegrasi Stem Untuk Meningkatkan Hasil Belajar Peserta Didik SMP Negeri 26 Palembang. Prosıdıng Semınar Nasıonal Pendıdıkan Program Pascasarjana Universitas PGRI Palembang, 293-304.

Idris, N., \& Nor, N. M. (2010). Mathematical creativity: Usage of technology. Procedia-Social and Behavioral Sciences, 2(2), 1963-1967. Elsevier.

Kamid, Resmita, \& Rohati. (2016). Analisis Nilai-Nilai Budaya Jambi Yang Terkandung Dalam Alat Musik Kelintang Kayu Yang Berkaitan Dengan Pembelajaran Pola Barisan Dan Deret. Aksioma, 5(3).

Lantas. (2004). Matematika, Materi Pelatihan Penilaian Alternatif. Jakarta: Depdiknas.

Mayer, R. E. (2002). Multimedia learning. Psychology of learning and motivation (Vol. 41, pp. 85-139). Elsevier.

Nieveen, N. (1999). Prototyping to reach product quality. Design approaches and tools in education and training (pp. 125-135). Springer.

Nugraha, D. W. (2011). Aplikasi algoritma prim untuk menentukan minimum spanning tree suatu graf berbobot dengan menggunakan pemrograman berorientasi objek. FORISTEK: Forum Teknik Elektro dan Teknologi Informasi (Vol. 1).

Rusdi, M. (2018). Penelitian Desain dan Pengembangan Kependidikan. Depok: PT. RajaGrafindo Persada. Sardjiyo, \& Pannen. (2010). Pembelajaran Berbasis Budaya: Model inovasi pembelajaran dan implementasi kurikulum berbasis kompetensi. Jurnal Pendidikan, 6(2), 83-98.

Subakti, D. P., Marzal, J., \& Hsb, M. H. E. (2021). Pengembangan E-LKPD Berkarakteristik Budaya Jambi Menggunakan Model Discovery Learning Berbasis STEM Untuk Meningkatkan Kemampuan Berpikir Kreatif Matematis. Jurnal Cendekia: Jurnal Pendidikan Matematika, 5(2), 1249-1264.

Sugiyono, S. (2010). Metode penelitian kuantitatif dan kualitatif dan R\&D. Alfabeta Bandung.

Supriadi, S. (2017). Mengembangkan Kemampuan Berpikir Kreatif Matematik Mahasiswa Pendidikan Guru Sekolah Dasar melalui Pembelajaran Etnomatematika Sunda. Jurnal Pengajaran MIPA, 22(1).

Vezzali, L., Gocllowska, M. A., Crisp, R. J., \& Stathi, S. (2016). On the relationship between cultural diversity and creativity in education: The moderating role of communal versus divisional mindset. Thinking Skills and Creativity, 21, 152-157. Elsevier.

Zainul, A., \& Nasution, N. (2001). Penilaian hasil belajar. Jakarta: Departemen Pendidikan Nasional. 